\title{
Managerial and Market-Based Appraisal of Agriculture Banking Using ANP and ELECTRE Method
}

\author{
Hasan Dinçer ${ }^{1, *}$, Ümit Hacioğlu ${ }^{1} \&$ Serhat Yüksel ${ }^{2}$ \\ ${ }^{1}$ School of Business and Management, Istanbul Medipol University, Beykoz, 34810, Istanbul, Turkey \\ ${ }^{2}$ Faculty of Social Sciences and Humanities, Konya Food and Agriculture University, Konya, Turkey. E-mail: \\ serhat.yuksel@gmail.com \\ *Correspondence: School of Business and Management, Istanbul Medipol University, Beykoz, 34810, Istanbul, \\ Turkey. E-mail: hdincer@medipol.edu.tr
}

Received: June 12, 2016

doi:10.5430/mos.v3n3p29
Accepted: June 21, 2016 Online Published: July 24, 2016

URL: http://dx.doi.org/10.5430/mos.v3n3p29

\begin{abstract}
Agricultural sector plays a very important role for the economies of the countries. It satisfies food needs of the people, provides raw materials to the industry sector and decrease unemployment rate and current account deficit problem. However, agricultural sector has some structural problems, such as periodic income, but continuous costs and need for modern and expensive machines. Because of these problems, agricultural producers should obtain necessary finance in order to increase their competitive powers. Banks are important institutions providing financial sources to agricultural producers to be effective in agricultural sector while minimizing the problems of producers. Based on the issues in the field, this study aims to identify the performance of Turkish banks regarding agricultural sector. Within this scope, we analyzed the performance of state-owned, privately-owned and foreign banks in Turkey separately. In this study, ANP (analytic network process) and ELECTRE (elimination and choice translating reality) methods have been used in order to achieve the objective of this study. As a result of this analysis, it was determined that with respect to net superior values, privately-owned banks have the greatest value in comparison with other banking groups. On the other hand, regarding net inferior values, foreign banks have the best performance. These two results show that state-owned banks do not have the highest performance. This situation identifies that the popularity of agriculture sector increased very much in Turkey so that privately-owned banks and foreign banks started to give more importance to this sector.
\end{abstract}

Keywords: management; performance evaluation; banking sector; agriculture banking; ANP; ELECTRE

\section{Introduction}

Agricultural sector satisfies the needs vital needs of the people in the country, such as food needs (Aksu, 2012). In addition to this situation, this sector helps to decrease unemployment rate by employing more people in the country (Adam, 2016). Furthermore, it provides raw material to industry sector that is based on agriculture (Barani et. al., 2015). Additionally, agriculture sector increases exports of the country (Patnaik, 1996). Owing to this situation, it affects current account balance of the country positively. While taking into consideration of these issues, it can be said that agriculture sector plays an essential role for the economies of the countries (Demetriades et. al., 1998).

Nevertheless, agriculture sector has some systematic problems because of its nature. For example, because this sector depends on the type of the climate, the income has to be periodic (Chisasa and Makina, 2013). In other words, agricultural producers have to wait for a long time in order to generate income. In spite of this situation, the costs of these producers are continuous. That is to say, the costs of the producers, such as supplying raw materials, production, storing and marketing goods and wages of the employees should be met before earning periodic income. This means that agricultural producers have maturity mismatch with respect to their costs and revenues (Rahman et. al., 2014).

Another problem of agricultural sector is that modern machines should be used in order to increase production (Terin et. al., 2014). As a result of this issue, it will be possible to raise the efficiency. However, most of these machines are 
very expensive for the producers. Due to this situation, agricultural producers should get necessary finance so as to have these machines. If they cannot use them, they will lose competitive advantage. This aspect causes decreases in the revenue of these producers (Ekwere et. al., 2014).

Because of the problems emphasized above, it is very significant for agricultural producers to obtain necessary finance in order to save competitive advantage and increase revenue (Hartarska et. al., 2015). Banks are the institutions that can provide this finance to the producers (Money, 2015). Despite this issue, some producers may provide finance from some different sources other than banks due to some problems. As an example, banks may not give loans to some agricultural producers since they cannot measure the credibility of these producers effectively (Ali, 2014).

Owing to this kind of problem, agricultural producers have to get finance some other sources, such as usurers. This situation increases the cost of finance for the producers because they have to pay higher amount of interest in this situation. As a result of this problem, many agricultural producers may lose their wealth and this situation leads to both economical and psychological problems. Due to this issue, it is very important to increase the effectiveness of the banks in agricultural sector. Hence, the studies related to this issue play a significant role in order to achieve this objective.

For that purpose, in this study, we aim to identify the performance of Turkish banks regarding agricultural sector. Within this scope, we try to analyze the performance of state-owned, privately-owned and foreign banks in Turkey separately. In addition to this situation, ANP and ELECTRE I methods are used in order to achieve this objective. Within this context, we define criteria so as to assess the performance of these banking groups with respect to agricultural sector. As a result of this analysis, it will be possible to compare the performance of the banking groups. Hence, it will be understood which banking groups are more effective in agricultural sector.

The paper is organized as follows. After introduction part, we explain managerial and market-based appraisal of agricultural banking. In this part, we describe 8 different criteria which will be used in the analysis part. Additionally, the third part gives information about ANP and ELECTRE I methods. Also, fourth part includes research and application to understand the performance of the banking groups in Turkey. Finally, the results of the analysis were given at conclusion.

\section{Performance Evaluation and Agriculture Banking}

It is very important to evaluate the performance of agricultural banks (Sarlak and Fard, 2009). In other words, it is significant to define appraisal criteria with respect to the performance of agriculture banking. Although some criteria may be similar to the traditional banking, there should be unique criteria in order to evaluate agriculture banking. Regarding the evaluation of agriculture banking, we can make either managerial or market-based appraisal. The main criteria are explained in Table 1.

Table 1. Appraisal Criteria of Agricultural Banking

\begin{tabular}{|c|c|c|}
\hline Appraisal Type & Appraisal Criteria & Reference \\
\hline \multirow{3}{*}{ Managerial-based } & The Number of Personnel & Ahmadi et. al. (2011), Chowdhury and Chowdhury (2011) \\
\hline & Operational Capacity & Ahmadi et. al. (2011) \\
\hline & Customer Support & Sarlak and Fard (2009) \\
\hline \multirow{5}{*}{ Market-based } & The Number of the Banks & $\begin{array}{l}\text { İloğlu (1964), Kliesen and Gilbert (1996), Bonin et. al. (2005), } \\
\text { Y1lmaz (2008), Chowdhury and Chowdhury (2011), Kandemir } \\
\text { (2010) }\end{array}$ \\
\hline & $\begin{array}{l}\text { The Number of the } \\
\text { Branches }\end{array}$ & $\begin{array}{l}\text { İloğlu (1964), Kliesen and Gilbert (1996), Bonin et. al. (2005), } \\
\text { Y1lmaz (2008), Chowdhury and Chowdhury (2011), Kandemir } \\
\text { (2010) }\end{array}$ \\
\hline & Deposits & Chowdhury and Chowdhury (2011) \\
\hline & Agricultural Loans & $\begin{array}{l}\text { Aruoba (1969), Belongia and Gilbert (1990), Firat and Çiçek } \\
\text { (2000), Kızılaslan and Köksal (2002), Anderson and Feder } \\
\text { (2003), Admassie (2004), Ellinger (1994), Yıldız and Oğuzhan } \\
\text { (2007), İnci (2010), Koçtürk et. al. (2012) }\end{array}$ \\
\hline & Total Assets & Armah et. al. (1999), Minh et. al. (2012) \\
\hline
\end{tabular}


As it can be seen in Table 1, we defined 8 appraisal criteria of agricultural banking. It was also determined that 3 of them are related to managerial-based criteria whereas there are 5 market-based criteria. Managerial appraisal criteria show that indicators which are related to the management of the banks. On the other hand, market-based criteria refer to the qualitative factors that give information about the performance of the banks.

Regarding managerial appraisal of agriculture banking, the number of the personnel is an important criterion. This shows the power of the banks in agriculture sector. In other words, when banks have more personnel, they have the chance to create new and effective projects in agriculture sector. Ahmadi et. al. (2011) made a study in order to analyze the performance of Iranian banks in agriculture sector. They concluded that the number of the personnel is the significant performance indicator. Also, Chowdhury and Chowdhury (2011) used the number of the personnel as a performance criterion.

Operational capacity of the banks is the second criterion in managerial-based appraisal of agriculture banking. It includes data security, IT background and the speed of problem solution related to these topics. Additionally, the physical conditions of the branches can be considered in this criterion. Ahmadi et. al. (2011) used operational capacity as an indicator so as to assess the performance of agricultural bank in Iran.

Another indicator related to managerial-based appraisal of agriculture banking performance is the customer support. It shows how a bank makes a communication with their customers. The main reason behind this situation is that customers give important feedbacks to the banks. If the banks give importance to this information, it may be possible for them to solve many problems. Sarlak and Fard (2009) made a study to see the effects of customer support in the performance of agriculture banking.

On the other hand, with respect to the market-based appraisal of agriculture banking, there are some important criteria. First of all, the number of the banks and the branches give important information as for the performance of the banks related to agriculture sector. İloğlu (1964) made an analysis about the importance of the banks in agriculture sector of Turkey. He concluded that Ziraat Bank is the most important bank for the agriculture sector by analysing the number of the banks and branches in Turkey. Kliesen and Gilbert (1996), Bonin et. al. (2005), Y1lmaz (2008), Chowdhury and Chowdhury (2011) and Kandemir (2010) also considered this criteria in their studies.

In addition to this aspect, the amount of deposit is accepted as a performance indicator in agriculture banking. The higher amount of the deposit shows that the more depositors trust this bank. That is to say, this criterion shows the credibility of the banks. Chowdhury and Chowdhury (2011) made a study so as to evaluate the performance of agricultural banks in Bangladesh. In this study, they used deposit amount of the banks as a performance indicator.

Another important criterion in order to appraise agriculture banking is the amount of agricultural loans of the banks. This criterion is effective to analyze the performance of the banks for only agriculture sector (Obilor, 2013), (Çevik and Zeren, 2014), (Adeyinka et. al., 2015), (Ahmad et. al., 2015). In other words, it does not give important information to analyze the performance of traditional banking. Aruoba (1969) analyzes the performance of Turkish banks in agriculture sector by using agricultural loans. Belongia and Gilbert (1990) also made similar analysis for USA while considering the same criterion. In addition to these studies, Fırat and Çiçek (2000), Kızılaslan and Köksal (2002), Anderson and Feder (2003), Admassie (2004), Ellinger (1994), Yıldız and Oğuzhan (2007), İnci (2010) and Koçtürk et. al. (2012) also used the amount of agricultural loans of the banks to identify the agricultural performance of the banks.

The amount of total assets of the banks is also a criterion in order to show the performance of agriculture banking. This criterion shows the size of the banks and gives information related to performance result. Armah et. al. (1999) tried to evaluate the performance of agricultural banks and concluded that large agricultural banks are more efficient. Minh et. al. (2012) made a study so as to analyze the efficiency of agricultural banks. They used the amount of total assets as a performance indicator in this study.

\section{ANP and ELECTRE Method}

\subsection{ANP Method}

It is very important to determine the correct relationship between the variables. Many techniques were developed in order to analyze this relationship accurately. Analytic Network Process (ANP) is one of the new techniques that are used in complex situation. Saaty (1999) made a study so as to determine how to structure a decision problem. In this study, he identified the fundamentals of ANP. This new technique is very similar to the Analytic Hierarchy Process (AHP) developed also by Saaty in 1990. Nonetheless, the main difference of ANP from AHP is that it considers 
network structure instead of hierarchy. Because of this aspect, it was thought that ANP approach gives effective results.

The first stage in the implementation of ANP technique is the creation of the sub problems from the original problem (Dinçer et. al., 2016). Also, Saaty developed a qualitative scale in order to compare the importance of the variables. 9 different values of this scale are emphasized below (Chang et. al., 2015).

- $1=$ Equal importance

- $2=$ Weak

- $3=$ Moderately Important

- $4=$ Reasonably plus

- $5=$ Strong weight

- $6=$ Strong plus

- $7=$ Very well-built confirmed important

- $8=$ Very, very strong

- $9=$ Excessive importance

By obtaining the values from this scale, a matrix is created to make this qualitative variable as quantitative (Saaty, 1990). The details of this matrix are given below.

$\mathrm{A}=\left[\mathrm{a}_{\mathrm{ij}}\right]_{\mathrm{nxn}} \quad \mathrm{i}=1, \ldots, \mathrm{n} \quad \mathrm{j}=1, \ldots, \mathrm{n}$

In addition to this situation, the consistency of this matrix should be measured. The details of the consistency ratio (CR) are explained in the following equation.

$$
\mathrm{CR}=\frac{C I}{R I}
$$

In this equation, CI represents consistency index and RI gives information about random consistency. The critical value for consistency ratio was identified as " 0.1 ". If CR is less than this value, this means that the matrix is consistent (Saaty, 1990). The next stage in this process is the development of supermatrix. If the sum of the column in this supermatrix is less than " 1 ", it should be normalized. After normalization process, limit supermatrix is formed to see the effects of the variables in the long run. Finally, the best alternative is chosen (Dinçer et. al., 2016).

There are many studies in which ANP method was used in the literature. Meade and Presley (2002) and Mohanty and others (2005) used ANP to select the best project in resource and development. Sadeghi and others (2012) tried to select the best supplier by using this method. In addition to these studies, Shahabi and others (2014), SSevkli and others (2012) and Görener (2012) compared AHP and ANP in their studies. Additionally, Lam (2015) tried to design supply chain, Sakthivel and others (2014) selected the best biodiesel blend and Beltran and others (2014) analyzed investment projects by using ANP method.

\subsection{ELECTRE Method}

ELECTRE method is used to determine the best alternative by making pairwise comparison among the alternatives (Beccali et. al., 1998). In other words, it was aimed to identify better alternatives. This method was firstly created by Bernard Roy in 1968 (Dias and Climaco, 1999). The most important advantage of this method is that it is possible to consider both qualitative and quantitative data in the analysis. Another significant aspect of this method is that there is no need to have high amount of data in order to make analysis (Duckstein and Gershon, 1983).

There are some kinds of ELECTRE methods for multi criteria decision making process. One of the most used is ELECTRE I method. The steps of ELECTRE I method can be explained as follows:

First of all, starting matrix, which is also called as decision matrix, is created. In the rows of this matrix, there are decision points whereas evaluation factors are stated in the columns (Figueria and Roy, 2002). The details of this matrix are given below.

$$
A_{i j}=\left[\begin{array}{ccc}
a_{11} & \cdots & a_{1 n} \\
\vdots & \ddots & \vdots \\
a_{m 1} & \cdots & a_{m n}
\end{array}\right]
$$


In the matrix above, $\mathrm{A}_{\mathrm{ij}}$ represents the starting matrix. After creating starting matrix, standard decision matrix is calculated. The equation of this matrix is given below.

$$
x_{i j}=\frac{\mathrm{a}_{\mathrm{ij}}}{\sqrt{\sum_{\mathrm{i}=1}^{\mathrm{m}} \mathrm{a}_{\mathrm{ij}}^{2}}}
$$

In this equation, $\mathrm{x}_{\mathrm{ij}}$ identifies starting matrix while $\mathrm{a}_{\mathrm{ij}}$ refers to the components of starting matrix. The standard decision matrix is shown below.

$$
X_{i j}=\left[\begin{array}{ccc}
x_{11} & \cdots & x_{1 n} \\
\vdots & \ddots & \vdots \\
x_{m 1} & \cdots & x_{m n}
\end{array}\right]
$$

Third stage of this process is to define the weighted standard decision matrix. The experts, who evaluate the criteria, give values and as a result of this evaluation, weighted factor of each criterion is calculated. The details of the weighted matrix are given below (Pang and Chen, 2011).

$$
Y_{i j}=\left[\begin{array}{ccc}
w_{1} x_{11} & \cdots & w_{n} x_{1 n} \\
\vdots & \ddots & \vdots \\
w_{1} x_{m 1} & \cdots & w_{n} x_{m n}
\end{array}\right]
$$

In this matrix, " $\mathrm{w}_{\mathrm{i}}$ " represents weighted factors. Each of these weighted factors should be between " 0 " and " 1 " and the sum of all factors should be equal to "1". Moreover, in the next step, concordance $\left(\mathrm{C}_{\mathrm{kl}}\right)$ and discordance $\left(\mathrm{D}_{\mathrm{kl}}\right)$ matrixes are developed. In the creation of these matrixes, components of these matrixes are compared (Mousseau et. al., 2001). The concordance interval set is detailed below.

$$
C_{k l}=\left\{j, \mathrm{y}_{\mathrm{kj}} \geq \mathrm{y}_{\mathrm{lj}}\right\}
$$

On the other hand, discordance interval set is the following.

$$
D_{k l}=\left\{j, \mathrm{y}_{\mathrm{kj}}<\mathrm{y}_{\mathrm{lj}}\right\}
$$

Also, concordance interval matrix is calculated by using following equation.

$$
\mathrm{C}_{\mathrm{kl}}=\sum_{j \in C_{k l}} w_{j}
$$

In addition to this situation, calculation of discordance matrix is given below.

$$
\mathrm{D}_{\mathrm{kl}}=\frac{\max \left|y_{k j}-y_{l j}\right|}{\max \left|y_{m j}-y_{n j}\right|}
$$

In the equation above, " $\mathrm{m}$ " and " $\mathrm{n}$ " is used so as to calculate the weighted normalized value among all components in the row (Pang and Chen, 2011). Moreover, critical value for concordance index matrix is given below.

$$
\mathrm{C}^{*}=\frac{1}{m(m-1)} \sum_{\mathrm{k}=1}^{\mathrm{m}} \sum_{\mathrm{l}=1}^{\mathrm{m}} \mathrm{C}_{\mathrm{kl}}
$$

In the equation above, " $\mathrm{C}$ *" represents the critical value and " $\mathrm{m}$ " explains the number of decision points. If $\mathrm{C}_{\mathrm{kl}}$ is less than $\mathrm{C}^{*}$, this means that the component of concordance index matrix will be equal to " 0 ". However, in the opposite situation, it will be equal to "1" (Pang and Chen, 2011). Additionally, critical value for discordance index matrix is given below. 


$$
\mathrm{D}^{*}=\frac{1}{m(m-1)} \sum_{\mathrm{k}=1}^{\mathrm{m}} \sum_{\mathrm{l}=1}^{\mathrm{m}} \mathrm{D}_{\mathrm{kl}}
$$

Similarly, if $\mathrm{D}_{\mathrm{kl}}$ is less than $\mathrm{D}^{*}$, this means that the component of discordance index matrix will be equal to " 0 ". Also, for the opposite situation, it will be equal to " 1 ". The last version of this process is to make decision. In order to achieve this objective, the components, which have highest concordance and lowest discordance indexes, are chosen (Rogers and Bruen, 1998).

There are a lot of studies in which ELECTRE I method is used in the literature. Hatami-Marbini and Tavana (2011) made a study related to group decision making and concluded that ELECTRE approach reveals more useful information than TOPSIS method. Moreover, Almedia (2005) tried to determine the best service quality criteria by using ELECTRE I method. Furthermore, Shanian and Savadogo (2006) made a study related to the material selection of bipolar plates. In order to select the best alternative, they used ELECTRE I method.

Bojkovic et. al. (2010) made a study about cross-country transport-sustainability. In this study, the evaluation is made by using ELECTRE I method. In addition to this study, Cheng et. al. (2009) tried to analyze outsourcer selection by using ELECTRE I method. Moreover, Aytaç et. al. (2011) used this method so as to evaluate catering firm alternatives. Furthermore, Çelik and Ustasüleyman (2014) evaluated the service quality of GSM operators in Turkey.

\section{An Application on Turkish Banking Sector}

In this study, banking groups in Turkey have been considered for the possible ranking of alternatives. 8 criteria have been determined as number of banks, number of branches, number of deposit accounts, number of employees, agriculture loans (USD million), total assets (USD million), customer support and operational capacity (10 point likert-scales). Employee, customer and operational items of agriculture banking could be defined in the managerial criteria of the performance measurement. However, number of banks, number of branches, and deposit accounts as well as total assets could be appointed as market-based parameters in the performance ranking of the banks. Table 2 shows the selected performance criteria of the banking groups defined as state-owned banks, privately-owned banks, and foreign banks by the end of 2015.

Table 2. Selected Performance Criteria for the Agriculture Banking in Turkey by the End of 2015

\begin{tabular}{|c|c|c|c|c|c|c|c|c|}
\hline & $\begin{array}{c}\text { Number } \\
\text { of } \\
\text { Banks } \\
\text { (C1) }\end{array}$ & $\begin{array}{l}\text { Number } \\
\text { of } \\
\text { Branches } \\
\text { (C2) }\end{array}$ & $\begin{array}{c}\text { Number of } \\
\text { Deposit } \\
\text { Accounts } \\
\text { (C3) }\end{array}$ & $\begin{array}{c}\text { Number of } \\
\text { Employees } \\
\text { (C4) }\end{array}$ & $\begin{array}{l}\text { Agriculture } \\
\text { loans (USD } \\
\text { million) } \\
\text { (C5) }\end{array}$ & $\begin{array}{c}\text { Total } \\
\text { Assets } \\
\text { (USD } \\
\text { million) } \\
\text { (C6) }\end{array}$ & $\begin{array}{c}\text { Customer } \\
\text { support (10 } \\
\text { point scales) } \\
\text { (C7) }\end{array}$ & $\begin{array}{c}\text { Operationa } \\
1 \text { capacity } \\
\text { (10 point } \\
\text { scales) } \\
\text { (C8) }\end{array}$ \\
\hline $\begin{array}{l}\text { State-owned } \\
\text { banks (A1) }\end{array}$ & 3 & 3,681 & $71,533,211$ & 58,211 & 12,983 & 230,809 & 6 & 5 \\
\hline $\begin{array}{l}\text { Privately-ow } \\
\text { ned banks } \\
\text { (A2) }\end{array}$ & 9 & 4,299 & $56,519,998$ & 74,756 & 812 & 291,723 & 9 & 9 \\
\hline $\begin{array}{l}\text { Foreign } \\
\text { banks (A3) }\end{array}$ & 21 & 3,170 & $36,011,245$ & 62,646 & 1,826 & 204,647 & 8 & 7 \\
\hline
\end{tabular}

Source: The banks Association of Turkey, Financial Statements, Author Construction

As seen in the table, while state-owned banks own the moderate results, they have the highest number of deposit accounts and agriculture loans in the Turkish banking system. By the way, privately-owned banks have the best degrees in the number of branches, number of employee and total assets besides customer support and operational capacity. Foreign banks are the best in the number of banks in the banking group. 
The analysis has been constructed in the two main phases. In the first phase, the weights of the criteria have been calculated using ANP method. Normalized values of pairwise comparison matrix for the each criteria and alternatives have been computed using 9 point scales. Accordingly, weighted super matrix and limit matrix have been calculated for determining the weight of each criterion in table 3 and 4 respectively.

Table 3. Weighted Supermatrix

\begin{tabular}{llllllllllll}
\hline & $\mathrm{C} 1$ & $\mathrm{C} 2$ & $\mathrm{C} 3$ & $\mathrm{C} 4$ & $\mathrm{C} 5$ & $\mathrm{C} 6$ & $\mathrm{C} 7$ & $\mathrm{C} 8$ & $\mathrm{~A} 1$ & $\mathrm{~A} 2$ & $\mathrm{~A} 3$ \\
\hline $\mathrm{C} 1$ & 0.0000 & 0.0000 & 0.0000 & 0.0000 & 0.0000 & 0.0000 & 0.0000 & 0.0000 & 0.4160 & 0.1524 & 0.1105 \\
$\mathrm{C} 2$ & 0.0000 & 0.0000 & 0.0000 & 0.0000 & 0.0000 & 0.0000 & 0.0000 & 0.0000 & 0.1278 & 0.1461 & 0.1924 \\
$\mathrm{C} 3$ & 0.0000 & 0.0000 & 0.0000 & 0.0000 & 0.0000 & 0.0000 & 0.0000 & 0.0000 & 0.1058 & 0.1749 & 0.1831 \\
$\mathrm{C} 4$ & 0.0000 & 0.0000 & 0.0000 & 0.0000 & 0.0000 & 0.0000 & 0.0000 & 0.0000 & 0.0856 & 0.1136 & 0.1362 \\
$\mathrm{C} 5$ & 0.0000 & 0.0000 & 0.0000 & 0.0000 & 0.0000 & 0.0000 & 0.0000 & 0.0000 & 0.0623 & 0.0918 & 0.0379 \\
C6 & 0.0000 & 0.0000 & 0.0000 & 0.0000 & 0.0000 & 0.0000 & 0.0000 & 0.0000 & 0.0536 & 0.1284 & 0.1163 \\
C7 & 0.0000 & 0.0000 & 0.0000 & 0.0000 & 0.0000 & 0.0000 & 0.0000 & 0.0000 & 0.0820 & 0.1046 & 0.1118 \\
C8 & 0.0000 & 0.0000 & 0.0000 & 0.0000 & 0.0000 & 0.0000 & 0.0000 & 0.0000 & 0.0669 & 0.0882 & 0.1118 \\
A1 & 0.0605 & 0.3338 & 0.6479 & 0.1062 & 0.7235 & 0.2299 & 0.1416 & 0.1062 & 0.0000 & 0.0000 & 0.0000 \\
A2 & 0.5544 & 0.5247 & 0.2299 & 0.6333 & 0.0833 & 0.6479 & 0.5247 & 0.6333 & 0.0000 & 0.0000 & 0.0000 \\
A3 & 0.3851 & 0.1416 & 0.1222 & 0.2605 & 0.1932 & 0.1222 & 0.3338 & 0.2605 & 0.0000 & 0.0000 & 0.0000 \\
\hline
\end{tabular}

Table 4 presents that $\mathrm{C} 1$ has the highest degree of importance in the managerial and market-based criteria as $\mathrm{C} 5$ is the weakest important factor in the multiple evaluation criteria. $\mathrm{C} 3, \mathrm{C} 2, \mathrm{C} 4, \mathrm{C} 6, \mathrm{C} 7$, and $\mathrm{C} 8$ have the importance degrees consecutively.

Table 4. Limit Matrix

\begin{tabular}{cccccccccccc}
\hline & $\mathrm{C} 1$ & $\mathrm{C} 2$ & $\mathrm{C} 3$ & $\mathrm{C} 4$ & $\mathrm{C} 5$ & $\mathrm{C} 6$ & $\mathrm{C} 7$ & $\mathrm{C} 8$ & $\mathrm{~A} 1$ & $\mathrm{~A} 2$ & $\mathrm{~A} 3$ \\
\hline $\mathrm{C} 1$ & 0.0000 & 0.0000 & 0.0000 & 0.0000 & 0.0000 & 0.0000 & 0.0000 & 0.0000 & 0.2154 & 0.2154 & 0.2154 \\
$\mathrm{C} 2$ & 0.0000 & 0.0000 & 0.0000 & 0.0000 & 0.0000 & 0.0000 & 0.0000 & 0.0000 & 0.1519 & 0.1519 & 0.1519 \\
$\mathrm{C} 3$ & 0.0000 & 0.0000 & 0.0000 & 0.0000 & 0.0000 & 0.0000 & 0.0000 & 0.0000 & 0.1577 & 0.1577 & 0.1577 \\
$\mathrm{C} 4$ & 0.0000 & 0.0000 & 0.0000 & 0.0000 & 0.0000 & 0.0000 & 0.0000 & 0.0000 & 0.1112 & 0.1112 & 0.1112 \\
$\mathrm{C} 5$ & 0.0000 & 0.0000 & 0.0000 & 0.0000 & 0.0000 & 0.0000 & 0.0000 & 0.0000 & 0.0710 & 0.0710 & 0.0710 \\
$\mathrm{C} 6$ & 0.0000 & 0.0000 & 0.0000 & 0.0000 & 0.0000 & 0.0000 & 0.0000 & 0.0000 & 0.1049 & 0.1049 & 0.1049 \\
$\mathrm{C} 7$ & 0.0000 & 0.0000 & 0.0000 & 0.0000 & 0.0000 & 0.0000 & 0.0000 & 0.0000 & 0.1000 & 0.1000 & 0.1000 \\
C8 & 0.0000 & 0.0000 & 0.0000 & 0.0000 & 0.0000 & 0.0000 & 0.0000 & 0.0000 & 0.0879 & 0.0879 & 0.0879 \\
$\mathrm{~A} 1$ & 0.2767 & 0.2767 & 0.2767 & 0.2767 & 0.2767 & 0.2767 & 0.2767 & 0.2767 & 0.0000 & 0.0000 & 0.0000 \\
$\mathrm{~A} 2$ & 0.4878 & 0.4878 & 0.4878 & 0.4878 & 0.4878 & 0.4878 & 0.4878 & 0.4878 & 0.0000 & 0.0000 & 0.0000 \\
$\mathrm{~A} 3$ & 0.2355 & 0.2355 & 0.2355 & 0.2355 & 0.2355 & 0.2355 & 0.2355 & 0.2355 & 0.0000 & 0.0000 & 0.0000
\end{tabular}

In the second phase of the analysis, ELECTRE I method has been applied for ranking the banking groups with managerial and market-based criteria of the banks. Table 5 illustrates the normalized decision matrix by the normalization method. 
Table 5. Normalized Matrix

\begin{tabular}{|c|c|c|c|c|c|c|c|c|}
\hline & $\begin{array}{l}\text { Number } \\
\text { of } \\
\text { Banks } \\
\text { (C1) }\end{array}$ & $\begin{array}{l}\text { Number } \\
\text { of } \\
\text { Branches } \\
\text { (C2) }\end{array}$ & $\begin{array}{l}\text { Number } \\
\text { of Deposit } \\
\text { Accounts } \\
\text { (C3) }\end{array}$ & $\begin{array}{l}\text { Number of } \\
\text { Employees } \\
\text { (C4) }\end{array}$ & $\begin{array}{l}\text { Agriculture } \\
\text { loans (USD } \\
\text { million) } \\
\text { (C5) }\end{array}$ & $\begin{array}{l}\text { Total } \\
\text { Assets } \\
\text { (USD } \\
\text { million) } \\
\text { (C6) } \\
\end{array}$ & $\begin{array}{l}\text { Customer } \\
\text { support } \\
(10 \text { point } \\
\text { scales }) \\
(\mathrm{C} 7) \\
\end{array}$ & $\begin{array}{l}\text { Operational } \\
\text { capacity (10 } \\
\text { point scales) } \\
\text { (C8) }\end{array}$ \\
\hline $\begin{array}{l}\text { State-owned } \\
\text { banks (A1) }\end{array}$ & 0.1302 & 0.5675 & 0.7298 & 0.5125 & 0.9884 & 0.5436 & 0.4685 & 0.4016 \\
\hline $\begin{array}{l}\text { Privately-owned } \\
\text { banks (A2) }\end{array}$ & 0.3906 & 0.6627 & 0.5766 & 0.6582 & 0.0618 & 0.6871 & 0.6247 & 0.7229 \\
\hline $\begin{array}{l}\text { Foreign banks } \\
\text { (A3) }\end{array}$ & 0.9113 & 0.4887 & 0.3674 & 0.5515 & 0.1390 & 0.4820 & 0.6247 & 0.5623 \\
\hline \multicolumn{9}{|c|}{$\begin{array}{l}\text { Table } 6 \text { defines the weight } \\
\text { method. } \\
\text { Table 6. Weighted Matrix }\end{array}$} \\
\hline & $\begin{array}{l}\text { Number } \\
\text { of } \\
\text { Banks } \\
\text { (C1) }\end{array}$ & $\begin{array}{l}\text { Number } \\
\text { of } \\
\text { Branches } \\
\text { (C2) }\end{array}$ & $\begin{array}{l}\text { Number } \\
\text { of } \\
\text { Deposit } \\
\text { Accounts } \\
\text { (C3) }\end{array}$ & $\begin{array}{l}\text { Number of } \\
\text { Employees } \\
\text { (C4) }\end{array}$ & $\begin{array}{l}\text { Agriculture } \\
\text { loans (USD } \\
\text { million) } \\
\text { (C5) }\end{array}$ & $\begin{array}{l}\text { Total } \\
\text { Assets } \\
\text { (USD } \\
\text { million) } \\
\text { (C6) } \\
\end{array}$ & $\begin{array}{l}\text { Customer } \\
\text { support } \\
(10 \text { point } \\
\text { scales }) \\
\text { (C7) } \\
\end{array}$ & $\begin{array}{l}\text { Operational } \\
\text { capacity (10 } \\
\text { point scales) } \\
\text { (C8) }\end{array}$ \\
\hline $\begin{array}{l}\text { State-owned } \\
\text { banks (A1) }\end{array}$ & 0.0280 & 0.0862 & 0.1151 & 0.0570 & 0.0701 & 0.0570 & 0.0469 & 0.0353 \\
\hline $\begin{array}{l}\text { Privately-owned } \\
\text { banks (A2) }\end{array}$ & 0.0841 & 0.1007 & 0.0909 & 0.0732 & 0.0044 & 0.0721 & 0.0625 & 0.0635 \\
\hline $\begin{array}{l}\text { Foreign banks } \\
\text { (A3) }\end{array}$ & 0.1963 & 0.0742 & 0.0579 & 0.0613 & 0.0099 & 0.0506 & 0.0625 & 0.0494 \\
\hline
\end{tabular}

Table 7 shows the concordance and discordance interval sets to compute the interval index and matrices.

Table 7. Concordance and Discordance Interval Sets

\begin{tabular}{llll}
\hline $\mathbf{C}(\mathbf{1}, \mathbf{2})$ & $(3,5)$ & $\mathbf{D}(\mathbf{1}, \mathbf{2})$ & $(1,2,4,6,7,8)$ \\
$\mathbf{C}(\mathbf{1 , 3})$ & $(2,3,5,6)$ & $\mathbf{D}(\mathbf{1}, \mathbf{3})$ & $(1,4,7,8)$ \\
$\mathbf{C}(\mathbf{2 , 1})$ & $(1,2,4,6,7,8)$ & $\mathbf{D}(\mathbf{2 , 1})$ & $(3,5)$ \\
$\mathbf{C}(\mathbf{2 , 3 )}$ & $(2,3,4,6,7,8)$ & $\mathbf{D}(\mathbf{2 , 3 )}$ & $(1,5)$ \\
$\mathbf{C}(\mathbf{3}, \mathbf{1})$ & $(1,4,7,8)$ & $\mathbf{D}(\mathbf{3 , 1})$ & $(2,3,5,6)$ \\
$\mathbf{C}(\mathbf{3}, \mathbf{2})$ & $(1,5,7)$ & $\mathbf{D}(\mathbf{3 , 2})$ & $(2,3,4,6,8)$ \\
\hline
\end{tabular}

Table 8 presents the concordance and discordance interval matrix to determine the net superior values and net inferior values.

Table 8. Concordance and Discordance Interval Matrix

\begin{tabular}{cccccc}
\hline Concordance matrix & \multicolumn{5}{c}{ Discordance matrix } \\
\hline- & 0.2286 & 0.4854 & - & 0.8533 & 1 \\
0.7714 & - & 0.7136 & 1 & - & 1 \\
0.5146 & 0.3864 & - & 0.3581 & 0.2941 & - \\
\hline
\end{tabular}


Table 9. Net Superior and Inferior Values and Ranking the Banking Groups

\begin{tabular}{ccccc}
\hline Banking Groups & $\begin{array}{c}\text { Net Superior } \\
\text { Values }\end{array}$ & Ranking & Net Inferior Values & Ranking \\
\hline A1 & -0.5718 & 3 & 0.4952 & 2 \\
A2 & 0.8699 & 1 & 0.8527 & 3 \\
A3 & -0.2981 & 2 & -1.3478 & 1 \\
\hline
\end{tabular}

Table 9 clarifies the multiple performance results of banking group alternatives through net superior and inferior values. The analysis results demonstrate that $\mathrm{A} 2$ has the best degree while A1 has the worst degree in the net superior values. Nevertheless, A3 is placed in the first rank as A2 is ranked last based on the net inferior values.

\section{Conclusion}

The growth and sustainability of emerging economies rely on the successful contribution of agricultural sectors which demonstrate a very important role on employment. Increasing employment in economies, it helps also the financial stability. Additionally, the efficient use of agricultural facilities creates new export transactions with its impact on economic growth. As a result, it can be observed that agricultural sector has a positive effect on current account balance of the country. Notwithstanding this, there are some structural problems in agricultural sector. First of all, agricultural producers have to wait for a long time to get income due to climate condition whereas the costs are continuous. This situation causes maturity mismatch with respect to their costs and revenues. In addition to this issue, these producers need to have modern and expensive machines in order to increase their competitive power.

Based on structural problems in the agricultural sector, producers should get necessary financial sources to be more competitive. Within this scope, banks play crucial role in providing financing sources. As it is known, debt financing strategies in emerging countries become a costly way during financial crisis. In volatile market conditions, banks are demanding more gains in balance with increasing risks. This situation increases the cost of financing instruments for the producers because they have to pay higher amount of interest in this situation. As a result, the stability in the banking sector and the effective banking activities determine the success of debt financing strategies for producers in this sector. Therefore, the level of effectiveness in the banking sector should be assessed, examined and increased in efficient ways in order to boost the contribution of agricultural sector in emerging economies.

Within this perspective, in this study, the performance of Turkish banks regarding agricultural sector has been determines. We analyzed the performance of state-owned, privately-owned and foreign banks in Turkey separately. Moreover, ANP and ELECTRE I methods were used so as to achieve this objective. Within this context, 8 appraisal criteria of agricultural banking were defined. It was also determined that 3 of them are related to managerial-based criteria whereas there are 5 market-based criteria.

As a result of this analysis, it was defined that regarding net superior values, privately-owned banks have the greatest value in comparison with other banking groups. Additionally, foreign banks have the second performance. Moreover, state banks are the banking group that has the lowest performance in agricultural sector. On the other hand, with respect to the net inferior values, foreign banks have the lowest value that means they have the best performance. Furthermore, state-owned banks are the second banking group whereas privately-owned banks have the lowest performance.

According to the results of the analysis considering both net superior values and net inferior values, it was concluded that state-owned banks do not have the highest performance. Although state-owned banks are thought to be more active in agriculture sector in Turkey, our analysis result showed the opposite issue. This situation identifies that the popularity of agriculture sector increased very much in Turkey so that privately-owned banks and foreign banks started to give more importance to this sector.

\section{References}

Adam, H. A. (2016). The Role of Agricultural Bank of Sudan in micro financing Rural Women (Doctoral dissertation, university of Khartoum). 
Adeyinka, A. J., Daniel, A. A., \& Olukotun, G. A. (2015). An Assessment of the Contributions of Commercial Banks to Agricultural Financing in The Nigerian Economy. International Journal of Advanced Academic Research Social Sciences and Education, 1(2), 1-16.

Admassie, A. (2004, December). A Review of the performance of agricultural finance in Ethiopia: pre-and-post reform periods. In International Conference on Agrarian Constraints and Poverty Reduction on (pp. 17-18).

Ahmad, A., Jan, I., Ullah, S., \& Pervez, S. (2015). Impact of agricultural credit on wheat productivity in District Jhang, Pakistan. Sarhad Journal of Agriculture, 31(1), 65-69.

Ahmadi, F., Habibi, F., \& Khodamoradi, A. (2011). The role of intellectual capital on improvement performance of agricultural bank in Iran. Interdisciplinary Journal of Contemporary Research in Business, 3(3), 1116.

Aksu, E. (2012). 2003-2011 Yılları Arasında Tarımsal Krediler ile Tarım Sektörü Arasındaki Nedensellik İlişkileri. Eskişehir Osmangazi Üniversitesi Sosyal Bilimler Enstitüsü İktisat Anabilim Dalı Yüksek Lisans Tezi.

Ali, D. A., Deininger, K., \& Duponchel, M. F. (2014). Credit constraints, agricultural productivity, and rural nonfarm participation: evidence from Rwanda. World Bank Policy Research Working Paper, (6769).

Almeida, A. T. (2005). Multicriteria modelling of repair contract based on utility and ELECTRE I method with dependability and service quality criteria. Annals of Operations Research, 138(1), 113-126.

Anderson, J. R., \& Feder, G. (2003). Rural extension services. World bank policy research working paper, (2976).

Armah, B. K., Park, T. A., \& Lovell, C. K. (1999). Evaluating the performance of agricultural bank management: the impact of state regulatory policies. Journal of Agricultural and Applied Economics, 31(03), 437-448. http://dx.doi.org/10.1017/S1074070800008750

Aruoba, Ç. (1969). Türkiye de Tarım Kredileri ve Tarımsal Yatırım İlişkileri. Ankara Üniversitesi SBF Dergisi, 24(3), 277-298. http://dx.doi.org/10.1501/SBFder_0000001155

Aytaç, E., Tuş Işik, A., \& Kundakci, N. (2011). Fuzzy ELECTRE I Method for Evaluating Catering Firm Alternatives. Ege Academic Review, 11, 125-134.

Barani, N., Menhaj, M. H., Ramezanpoor, E., \& Borazjani, M. A. (2015). Investigating the Impacts of Credits Granted by Agricultural Bank of Iran on Economic Conditions of Farmers in Hirmand Region. International Journal of Agricultural Management and Development, 5(2), 73-80. http://dx.doi.org/10.5455/ijamd.164272

Beccali, M., Cellura, M., \& Ardente, D. (1998). Decision making in energy planning: the ELECTRE multicriteria analysis approach compared to a fuzzy-sets methodology. Energy Conversion and Management, 39(16), 1869-1881. http://dx.doi.org/10.1016/S0196-8904(98)00053-3

Belongia, M. T., \& Gilbert, R. A. (1990). The effects of management decisions on agricultural bank failures. American journal of agricultural economics, 72(4), 901-910. http://dx.doi.org/10.2307/1242622

Beltrán, P., Chaparro-González, F., Pastor-Ferrando, J. P., \& Pla-Rubio, A. (2014). An AHP (Analytic Hierarchy Process)/ANP (Analytic Network Process)-based multi-criteria decision approach for the selection of solar-thermal power plant investment projects. Energy, 66, 222-238. http://dx.doi.org/10.1016/j.energy.2013.12.016

Bojković, N., Anić, I., \& Pejčić-Tarle, S. (2010). One solution for cross-country transport-sustainability evaluation using a modified ELECTRE method. Ecological Economics, 69(5), 1176-1186. http://dx.doi.org/10.1016/j.ecolecon.2010.01.006

Bonin, J. P., Hasan, I., \& Wachtel, P. (2005). Bank performance, efficiency and ownership in transition countries. Journal of Banking \& Finance, 29(1), 31-53. http://dx.doi.org/10.1016/j.jbankfin.2004.06.015

Çelik, P., \& Ustasüleyman, T. (2014). ELECTRE I ve PROMETHEE Yöntemleri İle GSM Operatörlerinin Hizmet Kalitesinin Değerlendirilmesi. Uluslararası Iktisadi ve İdari İncelemeler Dergisi, 12, 137-160. http://dx.doi.org/10.18092/ijeas.19566

Çevik, Z., \& Zeren, F. (2014). Tarım Kredilerinin Finansal Gelişim Üzerindeki Etkisinin Asimetrik Nedensellik Testi İle İncelenmesi. Yönetim ve Ekonomi Araştırmaları Dergisi, 12(24), 197-208. http://dx.doi.org/10.11611/JMER303

Chang, B., Kuo, C., Wu, C. H., \& Tzeng, G. H. (2015). Using fuzzy analytic network process to assess the risks in enterprise resource planning system implementation. Applied Soft Computing, 28, 196-207. http://dx.doi.org/10.1016/j.asoc.2014.11.025 
Cheng, Y., Wang, M. C., \& Feng, J. Y. (2009). Outsourcer selection based on noun-type attribute weights of ELECTRE-I. Journal of Tianjin University of Technology and Education, 4, 1-12.

Chisasa, J., \& Makina, D. (2013). Bank credit and agricultural output in South Africa: A Cobb-Douglas empirical analysis. The International Business \& Economics Research Journal (Online), 12(4), 387-398.

Chowdhury, T. A., \& Chowdhury, S. S. (2011). Performance evaluation of agricultural banks in Bangladesh. International Journal of Business and Management, 6(4), 75-89.

Demetriades, P. O., Devereux, M. P., \& Luintel, K. B. (1998). Productivity and financial sector policies: Evidence from South East Asia. Journal of economic behavior \& organization, 35(1), 61-82. http://dx.doi.org/10.1016/S0167-2681(97)00099-1

Dias, L. C., \& Clímaco, J. N. (1999). On computing ELECTRE's credibility indices under partial information. Journal of Multicriteria Decision Analysis, 8(2), 74-92.

Dincer, H., Hacioglu, U., \& Yuksel, S. (2016). Balanced Scorecard-based Performance Assessment of Turkish Banking Sector with Analytic Network Process. International Journal of Decision Sciences \& Applications-IJDSA, 1(1), 1-21.

Duckstein, L., \& Gershon, M. (1983). Multicriterion analysis of a vegetation management problem using ELECTRE II. Applied Mathematical Modelling, 7(4), 254-261. http://dx.doi.org/10.1016/0307-904X(83)90078-1

Ekwere, G. E., \& Edem, I. D. (2014). Effects of agricultural credit facility on the agricultural production and rural development. International Journal of Environment, 3(2), 192-204. http://dx.doi.org/10.3126/ije.v3i2.10529

Ellinger, P. N. (1994). Potential gains from efficiency analysis of agricultural banks. American Journal of Agricultural Economics, 76(3), 652-654. http://dx.doi.org/10.2307/1243684

Figueira, J., \& Roy, B. (2002). Determining the weights of criteria in the ELECTRE type methods with a revised Simos' procedure. European Journal of Operational Research, 139(2), 317-326. http://dx.doi.org/10.1016/S0377-2217(01)00370-8

Fırat, O., \& Çiçek, A. (2000). TC Ziraat Bankasının Tarımsal Kredi Uygulamaları ve Tokat ili Merkez İlçedeki İşletmelerin Bu Uygulamalardan Yararlanma Etkinliği Üzerine Bir Araştırma. Gaziosmanpaşa Üniversitesi Ziraat Fakültesi Dergisi, 1, 19-26.

Görener, A. (2011). Bütünleşik ANP-VIKOR Yaklaşımı ile ERP Yazılımı Seçimi. Havacıllk ve UzayTeknolojileri Dergisi, 5, 97-110.

Hartarska, V., Nadolnyak, D., \& Shen, X. (2015). Agricultural credit and economic growth in rural areas. Agricultural Finance Review, 75(3), 302-312. http://dx.doi.org/10.1108/AFR-04-2015-0018

Hatami-Marbini, A., \& Tavana, M. (2011). An extension of the Electre I method for group decision-making under a fuzzy environment. Omega, 39(4), 373-386. http://dx.doi.org/10.1016/j.omega.2010.09.001

İloğlu, A. S. (1964). Türkiye'de Zirai Kredi ve TC Ziraat Bankası. Sosyal Siyaset Konferansları Dergisi, (15), $89-118$.

İnci, İ. (2010). Cumhuriyet Dönemi Türkiye'sinde Tarımsal Kredi Konusundaki Gelişmeler. SAÜ Fen Edebiyat Dergisi, 91-116.

Kandemir, F. (2010). Dünya ve Türkiye'de Tarımın Finansmanı, T.C. Ziraat Bankası'nın Türkiye Tarımının Finansmanındaki Rolü. Kocaeli Üniversitesi Sosyal Bilimler Enstitüsü İktisat Anabilim Dalı Yüksek Lisans Tezi.

Kızılaslan, H., \& Köksal, Ş. (2002). Tarım İşletmelerinin Kredi Kullanımında Karşılaştıkları Sorunlar ve Çözüm Önerileri (Yozgat İli Merkez İlçe Örneği).Gaziosmanpaşa Üniversitesi Ziraat Fakültesi Dergisi, 1, 39-49.

Kliesen, K. L., \& Gilbert, R. A. (1996). Are Some Banks Too Agricultural?. Federal Reserve Bank of St. Louis, 78.

Lam, J. S. L. (2015). Designing a sustainable maritime supply chain: A hybrid QFD-ANP approach. Transportation Research Part E: Logistics and Transportation Review, 78, 70-81. http://dx.doi.org/10.1016/j.tre.2014.10.003

Meade, L. M., \& Presley, A. (2002). R\&D project selection using the analytic network process. IEEE transactions on engineering management, 49(1), 59-66. 
Minh, N. K., Van Khanh, P., \& Tuan, P. A. (2012). A new approach for ranking efficient units in Data Envelopment Analysis and Application to a Sample of Vietnamese Agricultural Bank Branches. American Journal of Operations Research, 2(01), 126-136. http://dx.doi.org/10.4236/ajor.2012.21015

Mohanty, R. P., Agarwal, R., Choudhury, A. K., \& Tiwari, M. K. (2005). A fuzzy ANP-based approach to R\&D project selection: a case study. International Journal of Production Research, 43(24), 5199-5216. http://dx.doi.org/10.1080/00207540500219031

Money, U. (2014). Bank Credits and Agricultural Development: Does it Promote Entrepreneurship Performance?. International Journal of Business and Social Science, 5(11), 102-107.

Mousseau, V., Figueira, J., \& Naux, J. P. (2001). Using assignment examples to infer weights for ELECTRE TRI method: Some experimental results. European Journal of Operational Research, 130(2), 263-275. http://dx.doi.org/10.1016/S0377-2217(00)00041-2

Obilor, S. I. (2013). The impact of commercial banks' credit to agriculture on agricultural development in Nigeria: An econometric analysis. International Journal of Business, Humanities and Technology, 3(1), 85-94.

Pang, J., Zhang, G., \& Chen, G. (2011). ELECTRE I decision model of reliability design scheme for computer numerical control machine. Journal of software, 6(5), 894-900. http://dx.doi.org/10.4304/jsw.6.5.894-900

Patnaik, U. (1996). Export-oriented agriculture and food security in developing countries and India. Economic and Political Weekly, 2429-2449.

Rahman, S., Hussain, A., \& Taqi, M. (2014). Impact of agricultural credit on agricultural productivity in Pakistan: An empirical analysis. International Journal of Advanced Research in Management and Social Sciences, 3(4), 125-139.

Rogers, M., \& Bruen, M. (1998). Choosing realistic values of indifference, preference and veto thresholds for use with environmental criteria within ELECTRE. European Journal of Operational Research, 107(3), 542-551. http://dx.doi.org/10.1016/S0377-2217(97)00175-6

Saaty, T. L. (1990). How to make a decision: the analytic hierarchy process. European journal of operational research, 48(1), 9-26. http://dx.doi.org/10.1016/S0377-2217(97)00175-6

Saaty, T. L. (1999). Decision making - the analytic hierarchy and network processes (AHP/ANP). Journal of systems science and systems engineering, 13(1), 1-35.

Sadeghi, M. (2012). Using analytic network process in a group decision-making for supplier selection. Informatica, 23(4), 621-643.

Sakthivel, G., Ilangkumaran, M., \& Gaikwad, A. (2015). A hybrid multi-criteria decision modeling approach for the best biodiesel blend selection based on ANP-TOPSIS analysis. Ain Shams Engineering Journal, 6(1), 239-256. http://dx.doi.org/10.1016/j.asej.2014.08.003

Sarlak, M. A., \& Fard, R. S. (2009). The impact of CRM on the customer satisfaction in agricultural bank. American Journal of Economics and Business Administration, 1(2), 167.

Sevkli, M., Oztekin, A., Uysal, O., Torlak, G., Turkyilmaz, A., \& Delen, D. (2012). Development of a fuzzy ANP based SWOT analysis for the airline industry in Turkey. Expert Systems with Applications, 39(1), 14-24. http://dx.doi.org/10.1016/j.eswa.2011.06.047

Shahabi, R. S., Basiri, M. H., Kahag, M. R., \& Zonouzi, S. A. (2014). An ANP-SWOT approach for interdependency analysis and prioritizing the Iran' s steel scrap industry strategies. Resources Policy, 42, 18-26. http://dx.doi.org/10.1016/j.resourpol.2014.07.001

Shanian, A., \& Savadogo, O. (2006). ELECTRE I decision support model for material selection of bipolar plates for Polymer Electrolyte Fuel Cells applications. Journal of New Materials for Electrochemical Systems, 9(3), 191-199.

Terin, M., Güler, İ. O., \& Aksoy, A. (2014). Türkiye'de Tarımsal Üretim ile Tarımsal Kredi Kullanımı Arasındaki Nedensellik İlişkisi. Iğdır Üni. Fen Bilimleri Enstitüsü Dergisi, 4(1), 67-72.

Yıldız, E. ve Oğuzhan, A. (2007). Türkiye'de Uygulanan Para Politikalarının Tarımsal Üretime Etkisi: Model Denemesi. Trakya Üniversitesi Sosyal Bilimler Dergisi, 9(2), 206-225.

Yılmaz, M. (2008). Dünya'da ve Türkiye'de Tarımsal Finansman:Türkiye Iç̧in Model Önerisi. Kadir Has Üniversitesi Sosyal Bilimler Enstitüsü Bankacılık Anabilim Dalı Yüksek Lisans Tezi. 